\title{
Can amphibians take the heat? Vulnerability to climate warming in subtropical and temperate larval amphibian communities
}

\author{
HELDER DUARTE*, MIGUEL TEJEDO*, MARCOKATZENBERGER*, FEDERICO \\ MARANGONI†, DIEGO BALDO†‡, JUAN FRANCISCO BELTRÁN §, DARDO ANDREA \\ MARTÍ†, ALEX RICHTER-BOIX $\|$ and ALEJANDRO GONZALEZ-VOYER** \\ *Department of Evolutionary Ecology, Estación Biológica de Doñana, CSIC, Avda. Américo Vespucio s/n, 41092 Sevilla, Spain, \\ †Laboratorio de Genética Evolutiva, FCEQyN-UNaM and Consejo Nacional de Investigaciones Científicas y Técnicas \\ (CONICET), Félix de Azara 1552, 6to Piso, 3300 Posadas, Misiones, Argentina, łFundación Miguel Lillo, Miguel Lillo 251,4000 \\ San Miguel de Tucumán, Tucumán, Argentina, §Departamento de Fisiología y Zoología, Facultad de Biología, Universidad de \\ Sevilla, Avda. Reina Mercedes, 6. 41012 Sevilla, Spain, ๆDepartment of Population Biology and Conservation Biology, \\ Evolutionary Biology Centre (EBC), Uppsala University, Norbyvägen 18 D, SE-752 36, Uppsala, Sweden, **Department of \\ Integrative Ecology, Estación Biológica de Doñana, CSIC, Avda. Américo Vespucio s/n, 41092 Sevilla, Spain
}

\begin{abstract}
Predicting the biodiversity impacts of global warming implies that we know where and with what magnitude these impacts will be encountered. Amphibians are currently the most threatened vertebrates, mainly due to habitat loss and to emerging infectious diseases. Global warming may further exacerbate their decline in the near future, although the impact might vary geographically. We predicted that subtropical amphibians should be relatively susceptible to warming-induced extinctions because their upper critical thermal limits $\left(\mathrm{CT}_{\max }\right)$ might be only slightly higher than maximum pond temperatures $\left(\mathrm{T}_{\max }\right)$. We tested this prediction by measuring $\mathrm{CT}_{\max }$ and $\mathrm{T}_{\max }$ for 47 larval amphibian species from two thermally distinct subtropical communities (the warm community of the Gran Chaco and the cool community of Atlantic Forest, northern Argentina), as well as from one European temperate community. Upper thermal tolerances of tadpoles were positively correlated (controlling for phylogeny) with maximum pond temperatures, although the slope was steeper in subtropical than in temperate species. $\mathrm{CT}_{\max }$ values were lowest in temperate species and highest in the subtropical warm community, which paradoxically, had very low warming tolerance (CT $_{\text {max }}-$ $\mathrm{T}_{\max }$ ) and therefore may be prone to future local extinction from acute thermal stress if rising pond $\mathrm{T}_{\max }$ soon exceeds their $\mathrm{CT}_{\max }$. Canopy-protected subtropical cool species have larger warming tolerance and thus should be less impacted by peak temperatures. Temperate species are relatively secure to warming impacts, except for late breeders with low thermal tolerance, which may be exposed to physiological thermal stress in the coming years.
\end{abstract}

Keywords: amphibian decline, global warming, species extinction risk, upper thermal tolerance, warming tolerance

\section{Introduction}

Global warming has caused significant changes in species distribution patterns, the structure and functioning of ecosystems and the timing of biological processes, following the mean $0.6{ }^{\circ} \mathrm{C}$ increase in Earth's temperature during the past century (Root et al., 2003; Parmesan, 2006). The predicted fivefold increase in warming rate in the coming decades, and the consequent increase in the number of extreme climatic events, may cause major extinctions (Sinervo et al., 2010). Trying to predict, buffer, and perhaps ameliorate these effects, is a major and urgent challenge currently faced by biolo-

Correspondence: Miguel Tejedo, tel. + 346295810 51, fax + 349546211 25, e-mail: tejedo@ebd.csic.es gists (Schwenk et al., 2009). However, most inferences on the biological consequences of global warming have been correlative and search for patterns rather than seeking for mechanisms relating physiological function and ecological performance that may allow for more precise predictions of the consequence of global climate change in the coming decades (Somero, 2005; Pö rtner \& Knust, 2007). In this context, a crucial question is to identify the species and communities currently living close to their upper thermal physiological limits, and that are exposed to higher risk of suffering physiological stress (Somero, 2005; Helmuth et al., 2010). The critical thermal maximum $\left(\mathrm{CT}_{\max }\right.$ ) (Cowles \& Bogert, 1944; Lutterschmidt \& Hutchison, 1997) is probably the most reliable parameter to conduct macrophysiological comparative studies in ectotherms and most suitable to 

explore how upper tolerances may evolve, and how it may vary across latitudes to predict which taxa and communities will be impacted more severely in the near future (Deutsch et al., 2008; Huey et al., 2009; Somero, 2010).

An emerging hypothesis from studies of impacts of warming on organisms proposes that ectothermic animals from low latitudes, tropical and subtropical areas, face considerably higher risk from environmental warming than do their temperate counterparts (Stillman \& Somero, 2000; Compton et al., 2007; Deutsch et al., 2008; Tewksbury et al., 2008; Huey et al., 2009; Dillon et al., 2010). This hypothesis is largely based on two assumptions: (1) Low-latitude tropical ectotherms are exposed to warmer environmental temperatures (Clarke \& Gaston, 2006) relative to their optimal temperatures than are temperate and high latitude ectotherms (Deutsch et al., 2008; Tewksbury et al., 2008) and, (2) Physiological upper thermal limits do not correlate with latitude or they increase at a slower rate than environmental temperatures. Thus, low-latitude ectotherms would experience environmental temperatures closer to their upper thermal thresholds (Addo-Bediako et al., 2000; Somero, 2002; Compton et al., 2007; Deutsch et al., 2008; Huey et al., 2009; Sunday et al., 2011). One way to test this hypothesis, and to assess the direct impact of global warming across latitudes and among communities, involves estimating geographical patterns of warming tolerance (WT), which is the difference between species' upper critical thermal limit $\left(\mathrm{CT}_{\max }\right)$ and its current maximum environmental temperature $\left(\mathrm{T}_{\max }\right)$ (Lutterschmidt \& Hutchison, 1997; Somero, 2005; Deutsch et al., 2008). If WT is large, individuals of a given species can potentially tolerate considerable warming before temperatures become deleterious and ultimately lethal.

Current information appears to support the second assumption because $\mathrm{CT}_{\max }$ is typically rather invariant with latitude (Brattstrom, 1968; Addo-Bediako et al., 2000; Ghalambor et al., 2006; Huey et al., 2009) or, when it does correlate with environmental temperature, $\mathrm{CT}_{\max }$ increases at a slower rate than maximum habitat temperature (Stillman \& Somero, 2000; Compton et al., 2007). However, the assumption that the low latitude tropical areas are physiologically warmer than the temperate zones may be an oversimplification because spatial and temporal patterns of operative body temperatures can be complex and can differ from mean environmental temperature. For instance, temperatures during the active season can be much warmer in some temperate areas than in the tropics (Helmuth et al., 2010). In addition, tropical environments may actually be cooler than some temperate regions. In fact, high Andean tropical frogs may be exposed to colder temperatures (Navas, 1997) and most tropical forest lizards have lower field body temperatures than do temperate zone, open-habitat species (Huey et al., 2009). Therefore, a precise estimation of actual operative temperature is crucial to any inference on the biological impact of global warming (Kearney et al., 2009a; Sinervo et al., 2010).

Amphibians are considered the most globally threatened group of vertebrates (Wake \& Vredenburg, 2008) with around $41 \%$ of its species classified as threatened (Hoffmann et al., 2010). In addition to the direct pressure of anthropogenic activities (e.g. habitat degradation, pollution) on amphibian environments and populations, other indirect factors associated or reinforced by global warming have been suggested, such as emerging infectious diseases, changes in the moisture content of terrestrial environments (Pounds et al., 2006) or shortening of pond hydroperiods (McMenamin et al., 2008). However, the direct effect of increasing maximum temperatures has generally been neglected as a direct causal factor of amphibian decline (Collins \& Crump, 2009) possibly because, so far, no evidence of lethal episodes of acute warming on any amphibian population have been reported (Carey \& Alexander, 2003). However, some amphibian communities (e.g. tropical montane salamanders with narrow distributions) are thought to be prone to extinction (Wake \& Vredenburg, 2008) due to, among other factors, warming-induced physiological depression (Bernardo \& Spotila, 2006).

In this report, we hypothesize that tropical and subtropical amphibian communities, which represent 80$90 \%$ of extant amphibian fauna (Wells, 2007), may be especially sensitive to increased environmental temperatures. Although tropical amphibians are relatively tolerant of high temperatures (Brattstrom, 1968; Snyder \& Weathers, 1975; but see Feder \& Lynch, 1982), they most likely already face relatively warm environmental temperatures, such that their warming tolerances might be relatively small. However, no systematic information of environmental temperatures to which amphibians are exposed is currently available and hence this hypothesis requires specific testing. We examine whether this prediction holds for the aquatic larval stage because upper thermal tolerances are not influenced by dehydration, as it presumably would affect $\mathrm{CT}_{\max }$ estimates in the terrestrial adult stage (Rezende et al., 2011). In addition, the relative small size of tadpoles, together with the high heat capacity and thermal diffusivity of water, makes them isothermal with the environment (Lutterschmidt \& Hutchison, 1997). Finally, although tadpoles are able to thermoregulate (Hutchison \& Dupré, 1992), they will unavoidably experience thermal stress, particularly in sunlit ponds. Any reduction in larval survival by chronic or acute thermal impacts, especially when pond temperature exceeds $\mathrm{CT}_{\max }$, could reduce juvenile recruitment rate 
affecting amphibian population sizes (Berven, 1990; Semlitsch et al., 1996; Hayes et al., 2010).

This study examines both $\mathrm{CT}_{\max }$ and $\mathrm{WT}$ in 47 larval amphibian species from three different thermal communities: a subtropical open-forest warm community, a subtropical cooler forest community, and a temperate cool community, to test two hypotheses. First, $\mathrm{CT}_{\max }$ in amphibian tadpoles are evolutionarily correlated with pond $\mathrm{T}_{\max }$. If so, subtropical species, which live in relatively warm temperatures, will have higher tolerances than temperate species have. Second, subtropical tadpole species will have $\mathrm{CT}_{\max }$ closer to current pond $\mathrm{T}_{\max }$ and, as a consequence, their $\mathrm{WT}$ will be smaller, putting them at higher risk of local extinctions than are temperate species.

\section{Materials and methods}

\section{Amphibian tadpole surveys}

We studied three thermally distinct amphibian communities: (1) the Gran Chaco region community (henceforth referred to as subtropical warm), northern Argentina (latitudinal range: $23^{\circ} 45^{\prime} \mathrm{S}-27^{\circ} 29^{\prime} \mathrm{S}$ ). Tadpole environments are temporary and ephemeral ponds, filled during summer rainy season. We sampled 16 species and seven ponds during November 2008February 2009. Maximum pond water temperatures ranged between 34.2 and $41.4{ }^{\circ} \mathrm{C}$ (Tables S1 and S2 in the electronic Supporting Information), (2) The Atlantic Forest community (subtropical cool), located in the Misiones province, NE Argentina (latitudinal range: $27^{\circ} 29^{\prime} \mathrm{S}-27^{\circ} 03^{\prime} \mathrm{S}$ ). Rainfall in this community is nearly aseasonal and although most of the species are summer breeders, three breed during fall to spring rains (Rhinella azarai, Melanophryniscus devincenzii and M. krauczuki). We examined 11 species from nine different ponds and streams during August 2009 to February 2010. Maximum water temperatures range between 21.3 and $30.4{ }^{\circ} \mathrm{C}$ (Tables S1 and S2) and, (3) The European community (temperate) (latitudinal range $36^{\circ} 56^{\prime} \mathrm{N}-60^{\circ} 31^{\prime} \mathrm{N}$ ). We examined 20 species from either the Iberian Peninsula (17 species) or Sweden (three species) sampling 18 different ponds and streams, both temporary and permanent, during February-June 2009 (Tables S1 and S2). Iberian and Swedish species were pooled in a single community as there were no significant differences in the examined variables (both $\mathrm{CT}_{\max }$ and $\mathrm{T}_{\max }$ showed $\mathrm{P}>0.05$ ). The breeding season encompasses early breeders, at southern locations, to early summer species from either the Iberian mountains or Sweden. Maximum water temperature ranged between 18.8 and $35.5{ }^{\circ} \mathrm{C}$.

\section{Upper thermal tolerance estimates $\left(\mathrm{CT}_{\max }\right)$}

$\mathrm{CT}_{\max }$ estimates may vary as a function of diverse methodological and biological sources that may bias any comparative study (see Navas et al., 2008). For instance, different methodological procedures, such as the selection of end-point (Lut- terschmidt \& Hutchison, 1997), ramping rates (Terblanche et al., 2007; Rezende et al., 2011), variations in previous thermal acclimation (Brattstrom, 1968), ontogenetic stage (Sherman, 1980), time of day and photoperiod, (Mahoney and Hutchison 1969) may promote shifts in amphibian upper thermal tolerances. To that end, we standardized $\mathrm{CT}_{\max }$ estimates for all the analysed species and communities as described below.

Field-sampled larvae were transported to each of the different laboratories at particular study sites (Argentina, CECOAL-CONICET, Corrientes 2009, FCEQyN-UNaM, Posadas, 2010; Spain, EBD-CSIC, Sevilla 2009; Sweden, EBC, Uppsala University, 2009). During all experiments larvae were maintained at a similar and constant room temperature of $20{ }^{\circ} \mathrm{C}$, with a natural photoperiod ca. $12: 12 \mathrm{~L}$ : D. Larvae were tested between 25 and 38 Gosner stages (Gosner, 1960). Tadpoles over 38 Gosner stage were excluded because such tadpoles (i.e. near metamorphic climax) have reduced thermal tolerances (Sherman, 1980; Floyd, 1983). Between 7 and 45 larvae of each species (see Table S1) were haphazardly selected, kept individually in plastic containers with $0.5 \mathrm{~L}$ water, and acclimatized for at least 4 days with food ad libitum. This acclimation period was chosen as previous research in adult amphibians revealed that between 2 and 3 days was the time required to stabilize $\mathrm{CT}_{\max }$ after a large change in acclimation temperature such as field and laboratory environments (Hutchison, 1961; Brattstrom, 1968). Upper critical thermal tolerances $\left(\mathrm{CT}_{\max }\right)$ were obtained using Hutchison's dynamic method, in which each animal was exposed to a constant heating rate of $1{ }^{\circ} \mathrm{C} \mathrm{min}-1$ until it reached the onset of muscular spasms, which signalled the endpoint of the experiment (Lutterschmidt \& Hutchison, 1997). The apparatus consisted of a magnetic stirrer hotplate fit to a water bath with a $250 \mathrm{~mL}$ test container filled with $200 \mathrm{~mL}$ of dechlorinated water at the acclimation temperature of $20{ }^{\circ} \mathrm{C}$. After $\mathrm{CT}_{\max }$ was determined, we transferred tadpoles to cold water to allow recovery, after which they were weighed and their Gosner stage registered. Each individual was tested only once. Finally, our interspecific approach, where we sampled only one population per species, ignores the eventual intraspecific variability in upper thermal tolerances (e.g. Hoppe, 1978; Wu \& Kam, 2005) and assumes that $\mathrm{CT}_{\max }$ values are species specific. However, our approach provides reliable estimates of $\mathrm{CT}_{\max }$ and consequent warming tolerances of each particular species. Furthermore, because of the range of species and the diversity of thermal environments sampled across the three communities included in the analyses, it is highly likely that any intra-specific differences in $\mathrm{CT}_{\max }$ would be overwhelmed by among species variation, and therefore that intra-specific variation is unlikely to bias our results (Ives et al., 2007).

\section{Environmental pond temperatures $\left(\mathrm{T}_{\max }\right)$}

To determine the thermal profile and the absolute maximum pond temperature $\left(\mathrm{T}_{\max }\right)$ for each species, we deployed a temperature data logger (HOBO Pendant) at the deepest bottom of each species collection pond, $(\mathrm{N}=34$ different ponds, 
see Table S2). The deepest part of the pond is its coolest region, never reaching the $\mathrm{T}_{\max }$ found in shallow areas (Newman, 1989; H. Duarte, M. Tejedo, M. Katzenberger, F. Marangoni, unpublished results). Therefore, the bottom of the pond is a microhabitat that tadpoles could eventually select under high peak temperatures. Temperature was recorded every 15-30 min. Temperatures were registered only when ponds held water during the reproductive season and coinciding with the larval presence of each species. Note that our estimate of pond $\mathrm{T}_{\max }$, taken at its coolest zone, results in warming tolerances estimates that can be considered conservative.

\section{Statistical analyses}

Phylogeny. We reconstructed a phylogenetic hypothesis for the 47 amphibian species based on published phylogenies (Frost et al., 2006). Branch lengths for the phylogeny were estimated based on three nuclear, protein-coding genes Rhodopsin, RAG-1, and Tyrosinase, and two mitochondrial genes cyt b and ND1 downloaded from GenBank (see Table S3 and Figure S1 in the electronic Supporting Information). Branch lengths were computed under a GTR $+\mathrm{I}+\Gamma$ model of substitution under maximum likelihood using PAUP* (Swofford, 2003). For 12 species, no sequence was available in GenBank and hence we used sequence information from a known sister-taxon to estimate branch lengths. As rate of molecular evolution can be influenced by many factors (Bromham, 2009), we also repeated the analyses using our phylogenetic topology setting all branch lengths equal to one.

Phylogenetic comparative analyses. Data collected across multiple species violate the basic assumption of statistical independence of observations (Felsenstein, 1985; Harvey \& Pagel, 1991; Garland et al., 1992); therefore, all statistical analyses were undertaken incorporating phylogenetic information. To evaluate the correlation between $\mathrm{CT}_{\max }$ and $\mathrm{T}_{\max }$, we used phylogenetic generalized least squares (PGLS) analyses under a Brownian motion model of evolution, in the package CAIC (Orme et al., 2009) in R (R Development core team, 2009). The PGLS model incorporates a parameter $(k)$, which adjusts the variance-covariance matrix so that the model fits the assumptions of the Brownian model of phenotypic evolution. A high value of lambda (i.e. $k=1$ ) indicates that the covariance between the traits follows that predicted under a Brownian model of trait evolution where variance in traits accumulates with time since divergence from a common ancestor, whereas values of $k<1$ indicate that the actual covariance between the traits is lower than would be expected under a Brownian model (Freckleton et al., 2002). Analyses included branch lengths estimated from molecular sequences on the composite topology (see above). We repeated these analyses using a topology with equal branch lengths and found similar results. For brevity, we present only results of the first case.

To analyse the influence of climatic region (subtropical vs. temperate) and community on $\mathrm{CT}_{\max }$, its coefficient of variation, $\mathrm{T}_{\max }$ and $\mathrm{WT}$, we used phylogenetic ANOva models in geiger (Harmon et al., 2009) in R (R Development core team, 2009). Previous analyses revealed that tadpole mass did not explain significant $\mathrm{CT}_{\max }$ variation, thus it was not included in the models.

\section{Results}

Maximum pond water temperatures $\left(\mathrm{T}_{\max }\right)$ were much higher on average for subtropical warm species than temperate or subtropical cool species, about +10 and $+12{ }^{\circ} \mathrm{C}$, respectively (phylogenetic Anovas, Table 1). $\mathrm{CT}_{\max }$ means were higher in subtropical than in temperate zone communities, and a larger coefficient of variation was found for the subtropical warm species in relation to temperate species (Fig. 1, Table 1). Within the subtropics, $\mathrm{CT}_{\max }$ values were higher for species

Table 1 Mean \pm SE for critical thermal maximum $\left(\mathrm{CT}_{\max }\right)$, coefficient of variation for $\mathrm{CT}_{\max }\left[\mathrm{CV}\left(\mathrm{CT} \mathrm{T}_{\max }\right)\right]$, maximum pond temperature $\left(\mathrm{T}_{\max }\right)$, and warming tolerance $\left(\mathrm{WT}, \mathrm{WT}=\mathrm{CT}_{\max }-\mathrm{T}_{\max }\right.$ ) and phylogenetic ANovas comparing different tadpole communities. Significant values $(\mathrm{P}<0.05)$ are shown in bold. Significance levels were not corrected for multiple comparisons because contrasts were based on a priori hypotheses

\begin{tabular}{|c|c|c|c|c|c|}
\hline & $\mathrm{N}$ & $\mathrm{CT}_{\max }\left({ }^{\circ} \mathrm{C}\right)$ & $\mathrm{CV}\left(\mathrm{CT}_{\max }\right)$ & $\mathrm{T}_{\max }\left({ }^{\circ} \mathrm{C}\right)$ & WT $\left({ }^{\circ} \mathrm{C}\right)$ \\
\hline Temperate & 20 & $38.1 \pm 0.29$ & $1.16 \pm 0.10$ & $28.7 \pm 1.2$ & $9.4 \pm 1.1$ \\
\hline $\begin{array}{l}\text { Subtropical } \\
(\text { warm + cool) }\end{array}$ & 27 & $41.4 \pm 0.34$ & $1.61 \pm 0.09$ & $34.0 \pm 1.3$ & $7.5 \pm 1.0$ \\
\hline Subtropical warm & 16 & $42.5 \pm 0.23$ & $1.60 \pm 0.11$ & $38.9 \pm 0.4$ & $3.5 \pm 0.4$ \\
\hline Subtropical cool & 11 & $39.9 \pm 0.48$ & $1.63 \pm 0.14$ & $26.7 \pm 1.0$ & $13.2 \pm 1.0$ \\
\hline $\begin{array}{l}\text { Subtropical vs. } \\
\text { temperate }\end{array}$ & & $\mathrm{F}_{1,45}=51.18, \mathrm{P}=0.005$ & $\mathrm{~F}_{1,45}=11.47, \mathrm{P}=0.242$ & $\mathrm{~F}_{1,45}=8.75, \mathrm{P}=0.312$ & $\mathrm{~F}_{1,45}=1.68, \mathrm{P}=0.656$ \\
\hline $\begin{array}{l}\text { Subtropical warm } \\
\text { vs. subtropical cool }\end{array}$ & & $\mathrm{F}_{1,25}=28.84, \mathrm{P}=0.001$ & $\mathrm{~F}_{1,25}=0.03, \mathrm{P}=0.887$ & $\mathrm{~F}_{1,25}=155.88, \mathrm{P}=0.001$ & $\mathrm{~F}_{1,25}=109.1, \mathrm{P}=0.001$ \\
\hline $\begin{array}{l}\text { Subtropical warm } \\
\text { vs. temperate }\end{array}$ & & $F_{1,34}=130.91, P=0.001$ & $F_{1,34}=10.64, P=0.021$ & $F_{1,34}=55.38, P=0.001$ & $\mathrm{~F}_{1,34}=21.34, \mathrm{P}=0.04$ \\
\hline $\begin{array}{l}\text { Subtropical cool } \\
\text { vs. temperate }\end{array}$ & & $\mathrm{F}_{1,29}=11.98, \mathrm{P}=0.133$ & $\mathrm{~F}_{1,29}=5.11, \mathrm{P}=0.178$ & $\mathrm{~F}_{1,29}=1.18, \mathrm{P}=0.636$ & $\mathrm{~F}_{1,29}=5.11, \mathrm{P}=0.323$ \\
\hline
\end{tabular}




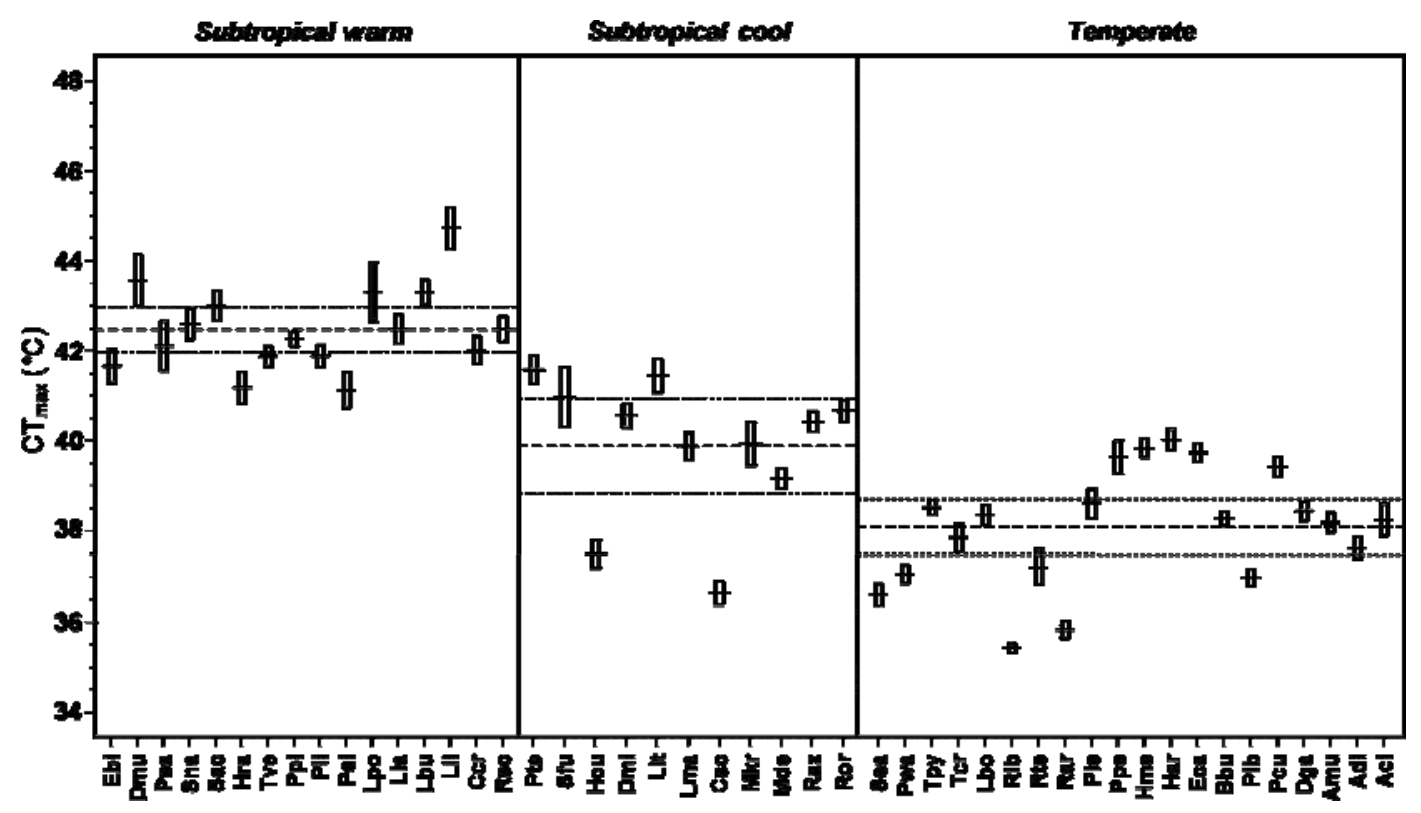

Fig. 1 Upper critical thermal limits $\left(\mathrm{CT}_{\max }\right)$ for three different amphibian tadpole communities: subtropical warm and cool communities from the Gran Chaco and Atlantic Forest, respectively, in northern Argentina, and temperate community from Europe. The average $\mathrm{CT}_{\max }$ for each species is represented by the middle line of boxplots, box height indicates upper and lower confidence intervals CI 95\%. Dashed and dotted lines indicate the average $\mathrm{CT}_{\max }$ and 95\% CI, respectively, for the overall community. Species codes, ordered phylogenetically within community, see Table S1.

living in hot ponds from the Gran Chaco than for those in the cooler Atlantic Forest (Fig. 1, Table 1). Thus, upper thermal tolerances appear to have evolved in relation to microhabitat maximum temperatures. In fact, $\mathrm{CT}_{\max }$ and $\mathrm{T}_{\max }$ are positively correlated (even when controlling for phylogenetic effects), but the slope is much less than 1.0 (Phylogenetic generalized least squares (PGLS), $b \pm \mathrm{SE}: 0.18 \pm 0.03, \mathrm{t}=5.893$, $\mathrm{P}=4.50388 \mathrm{e}^{-7}$ all communities, $0.19 \pm 0.03$ for both subtropical communities pooled, $0.07 \pm 0.05$ for temperate species, Fig. 2). The model explained a high proportion of the variance in $\mathrm{CT}_{\max }\left(\mathrm{R}^{2}=0.44\right)$, and the high value of lambda $(\mathrm{k}=0.89)$ suggests that there is an influence of the phylogeny on the covariance between the two traits.

Two major inferences can be derived from these results. First, although Gran Chaco tadpole species live in relatively warm ponds and have the highest upper thermal limits, they nonetheless have the lowest warming tolerances (Fig. 3, Table 1). Their low warming tolerance could be a consequence of a physiological constraint on thermal adaptation. PGLS regression of $\mathrm{CT}_{\max }$ on $\mathrm{T}_{\max }$ for both subtropical communities shows that a change in $\mathrm{T}_{\max }$ of $1{ }^{\circ} \mathrm{C}$ yields only a $0.2{ }^{\circ} \mathrm{C}$ correlated response in $\mathrm{CT}_{\max }$, indicating slower evolution of $\mathrm{CT}_{\text {max }}$ in response to changes in temperature (Fig. 2). Second, some temperate species also show low warm- ing tolerances even though they live in ponds that are relatively cool (Fig. 3, Table 1). Comparison of the PGLS regression slopes of $\mathrm{CT}_{\max }$ and $\mathrm{T}_{\max }$ between temperate and subtropical species shows marginally significant heterogeneity of slopes $\left(\mathrm{t}_{44}=-1.97\right.$, $\mathrm{P}=0.055$, Fig. 2). An increase in pond maximum temperature determines proportionally lower increases in $\mathrm{CT}_{\text {max }}$ in temperate species than in subtropical species and, as a consequence, the WT is lower for the former.

\section{Discussion}

Evolution of upper thermal limits $\left(\mathrm{CT}_{\max }\right)$ in amphibian larvae

Our results suggest that the variation in upper thermal tolerances for 47 amphibian species from temperate and subtropical habitats reflects adaptation to the prevalent maximum temperatures that larvae have to face in their ponds. Similar correlated evolution between tolerance limits and maximum microhabitat temperatures has previously been suggested for other ectotherms such as tidal porcelain crabs (Stillman \& Somero, 2000), bivalves (Compton et al., 2007) and Phrynosomatidae lizards (Sinervo et al., 2010). However, these findings contrast with those found for other ectotherms, for whom either $\mathrm{CT}_{\max }$ (Addo-Bediako 


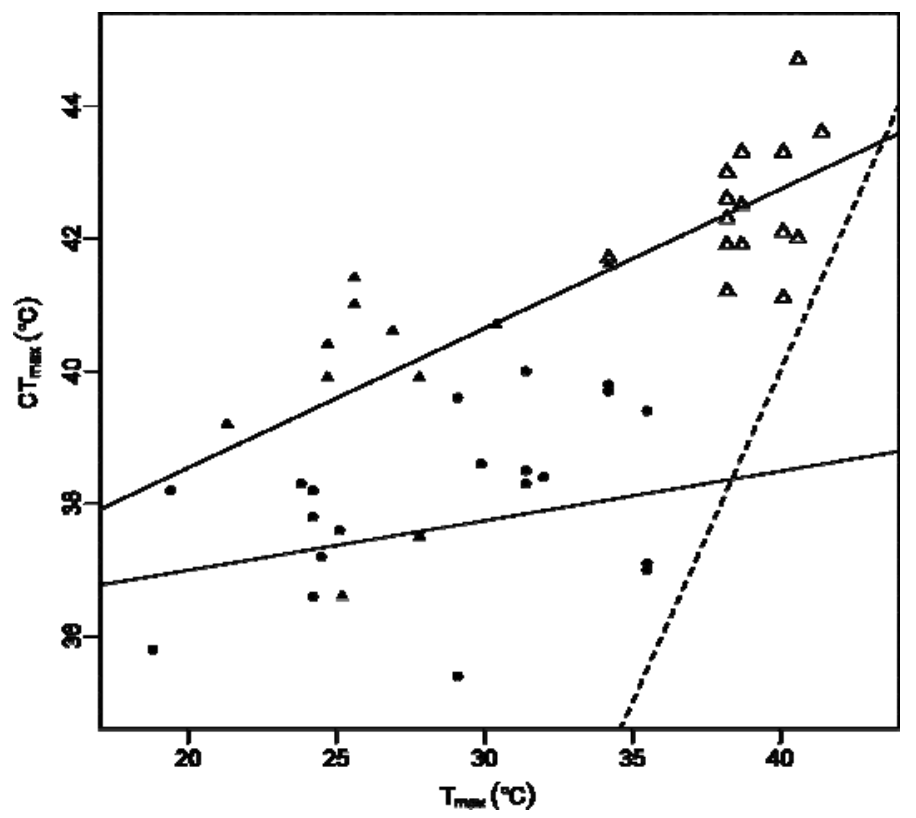

Fig. 2 Subtropical (upper line, $\mathrm{CT}_{\max }=34.93+0.19 \mathrm{~T}_{\max }, \mathrm{R}^{2}=0.63, \mathrm{t}=6.56, \mathrm{P}=7.22 \mathrm{e}^{-7}$ ) and temperarate (lower line, $\mathrm{CT}_{\max }=35.51$ $+0.07 T_{\max }, R^{2}=0.12 ; t=1.57, P=0.13$ ) community regressions for upper critical thermal limits $\left(\mathrm{CT}_{\max }\right)$ and maximum pond temperatures $\left(\mathrm{T}_{\max }\right)$. Species of two subtropical communities are represented in open (subtropical warm, Gran Chaco) and closed (subtropical cool, Atlantic Forest) triangles. Temperate species are represented in closed circles. The dashed line represents a lethal threshold $\left(\mathrm{CT}_{\max }=\mathrm{T}_{\max }\right)$, where warming tolerance is equal to zero. Proximity to this line allows estimation of the risk of death due to acute thermal stress for each species.

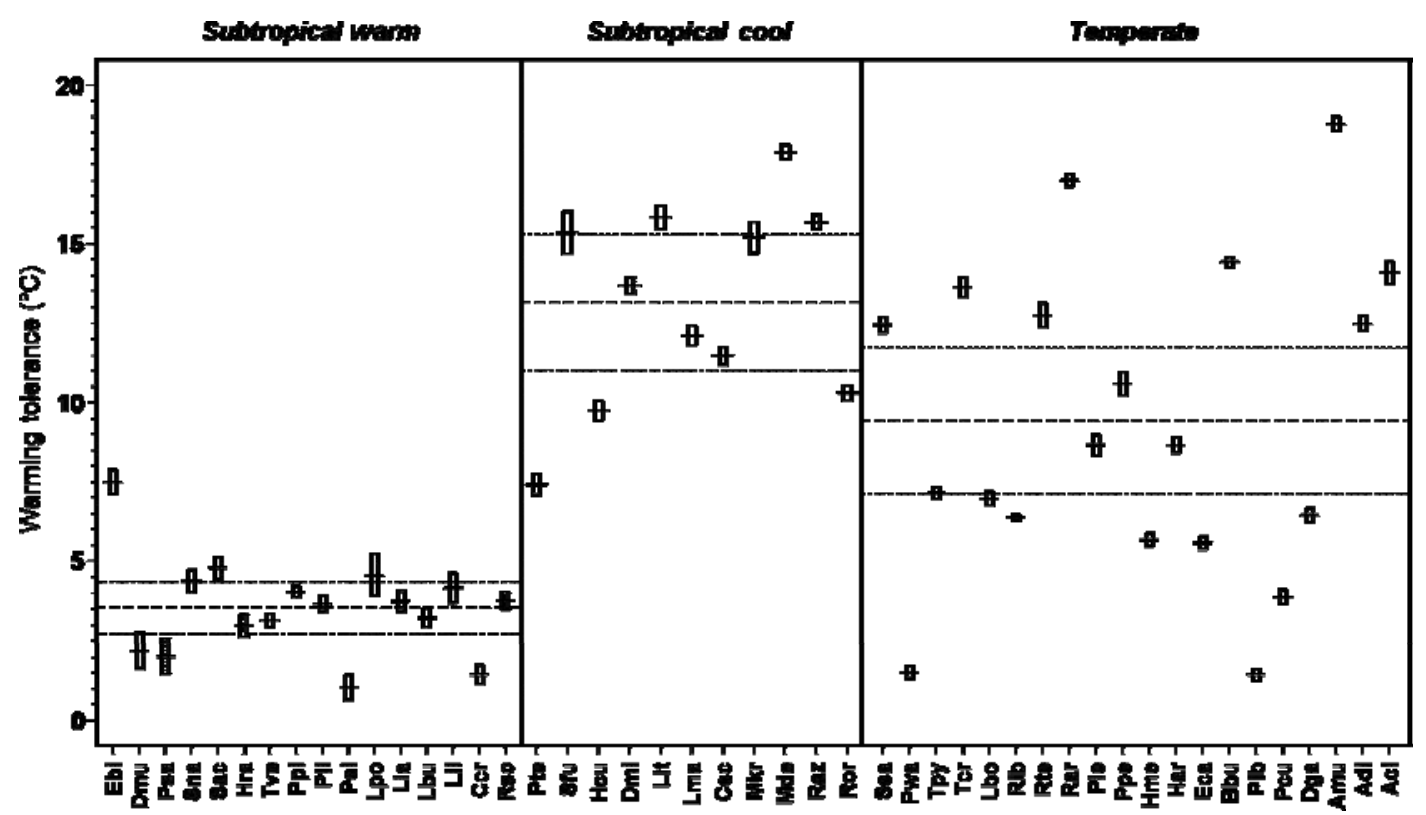

Fig. 3 Warming tolerance (WT) for different amphibian larvae communities. The average for each species is represented by the middle line of boxplots, box height indicates upper and lower confidence intervals CI 95\%. Dashed and dotted lines indicate the average WT and 95\% CI, respectively, for the overall community. Species codes, ordered phylogenetically within community, see Table S1. 
et al., 2000; Huey et al., 2009; Sunday et al., 2011) or maximum body temperature (Feder \& Lynch, 1982) did not exhibit a latitudinal trend, probably because maximum yearly air temperatures do not vary much with latitude (Addo-Bediako et al., 2000; Ghalambor et al., 2006) but see Sunday et al. (2011) for marine species.

Subtropical tadpoles from the Gran Chaco community, which are exposed to very hot ponds (see Table 1 and Table S2), have higher $\mathrm{CT}_{\max }$ (phylogenetic ANOvA) than both cooler subtropical Atlantic Forest and temperate communities. Interestingly, the two distinct subtropical communities encompass about twice the range of upper physiological limits than temperate taxa, even though for the latter, we examined species from a wider latitudinal gradient $\left(36-60^{\circ} \mathrm{N}\right.$, see Table S2). The broader range in $\mathrm{CT}_{\text {max }}$ for subtropical species is possibly due to the extremely high tolerances found in Chacoan warm-adapted species. Some of these species breed in sunlit ponds during summer, when pond temperatures can exceed $40{ }^{\circ} \mathrm{C}$. Some can even tolerate experimental heat pulses up to $45{ }^{\circ} \mathrm{C}$ (Carroll, 1996). On the other hand, the lower upper thresholds of temperate species could be a consequence of lower $\mathrm{CT}_{\text {min }}$ in cold-tolerant temperate species (Snyder \& Weathers, 1975; Ghalambor et al., 2006; based on data in Brattstrom, 1968). If there are physiological or genetic constraints involved in maintaining higher thermal tolerance limits, there may be a restraint in its evolution for cold-adapted species (Stillman \& Somero, 2000; Hoffmann et al., 2002; Pörtner et al., 2006).

Assessment of amphibian extinction risk in subtropical and temperate communities due to increased warming

Two main results lead us to conclude that our working hypothesis that tropical amphibians will face higher extinction risks from warming than temperate species is supported, but only in part. First, a striking distinction in warming risks exists between the two subtropical communities. On average, Gran Chaco pond $\mathrm{T}_{\max }$ was higher than the one of the Atlantic Forest by $12.2{ }^{\circ} \mathrm{C}$, whereas the difference in $\mathrm{CT}_{\max }$ was only of $2.6{ }^{\circ} \mathrm{C}$ (see Table 1). Thus, $\mathrm{CT}_{\max }$ in the Chacoan species may not have evolved fast enough to track the increment in $\mathrm{T}_{\max }$ and, as a consequence, most of the examined Chacoan amphibians have narrow warming tolerances (less than $3{ }^{\circ} \mathrm{C}$ ). This physiological constraint may limit thermal adaptation of warm-adapted organisms, such as larval amphibians and other ectotherms (Hochachka \& Somero, 2002). In general, most warmadapted marine invertebrates and lizards live close to their thermal limits and hence may be threatened by further increases in temperature (Compton et al., 2007;
Sinervo et al., 2010; Somero, 2010). The low warming tolerance values of the Gran Chaco community may lead to an extreme risk of extinction both because they are well within the predicted increase in average air temperature and because the intensification of extremely hot summers in the area might well lead to pond maximal temperatures exceeding upper thermal limits (Burgos \& Fuenzalida-Ponce, 1991; IPCC, 2007; Battisti $\&$ Naylor, 2009). Although pond temperature changes due to global warming have not been modelled, the temperature of unshaded ponds rises with an increase in air temperature (Kearney et al., 2009b).

Tadpole species from the cooler ponds and streams of the Atlantic Forest, on the contrary, have warming tolerances averaging $13.2{ }^{\circ} \mathrm{C}$ (see Table 1) and thus should be relatively safer from thermal stress episodes. Interestingly, this finding contrasts with the much higher impact predicted for other tropical forest ectotherms, such as lizards (Deutsch et al., 2008; Huey et al., 2009). However, even though forest tadpoles may be relatively less vulnerable to warming than are Chacoan ones, they may still be at risk since we have not considered the vulnerability of terrestrial adult frogs, which can be affected by warming-related decreases in air moisture and pathogen outbreaks (Pounds et al., 2006) or by habitat deforestation (Becker et al., 2007).

With regard to our second main conclusion, although many temperate species have high warming tolerances (Fig. 3), some Iberian species (Pelodytes ibericus, Pleurodeles waltl, Pelobates cultripes) that breed late in spring may expose their tadpoles to high temperatures. These temperate species have lower relative upper thermal tolerances than subtropical frogs because their increase in $\mathrm{CT}_{\max }$ scales with a lower slope to $T_{\max }$. The slower thermal adaptation in temperate species leads to small warming tolerances $\left(<4{ }^{\circ} \mathrm{C}\right)$, similar in magnitude to those found for the Chacoan frogs. Another factor that may increase the vulnerability of temperate species is that, although they have on average larger warming tolerances than subtropical communities, the rate of warming is predicted to be faster in the temperate zone (IPCC, 2007). Therefore, having a large warming tolerance in the temperate zone may not help as much as it would if warming was uniform with latitude (Hoffmann, 2010).

A final concern is that our $\mathrm{CT}_{\max }$ values may be overestimated as, under slower and more realistic heating rates than the ones we have used, $\mathrm{CT}_{\max }$ values tend to be lower (Chown et al., 2009; Rezende et al., 2011; M. Tejedo, H. Duarte, M. Simon \& M. Katzenberger, unpublished results). If this occurs in most of the species we analysed, then warming tolerances may in fact be even smaller than those shown here. 
Can larval amphibians take the heat?

The potentially important effect of peak temperatures on species with low warming tolerances could be partially mitigated by several compensatory responses such as acclimation (Floyd, 1983), thermoregulatory behaviour (Hutchison \& Dupré, 1992), shifts in breeding phenology (Beebee, 1995; Bradshaw \& Holzapfel, 2006) or evolutionary adaptive responses (Skelly et al., 2007). However, all of these reveal a limited capacity to change physiological upper tolerances in invertebrate ectotherms (Cavicchi et al., 1995; Stillman, 2003; Kellermann et al., 2009), and also in amphibians, with low acclimation scope, both along latitudinal and altitudinal gradients (Brattstrom, 1968; for adults; H. Duarte, M. Tejedo, M. Katzenberger, F. Marangoni, unpublished results, for larvae). Interestingly, coefficients of variation for $\mathrm{CT}_{\max }$ were significantly larger for the subtropical warm Chaco community than for the temperate community (see Table 1), which may suggest a higher evolutionary potential for the former, considering that the observed phenotypic variance reflects a significant additive component (Houle, 1992).

\section{Conclusions}

Determining the communities and species most vulnerable to climate warming is a challenging but important task (Sinervo et al., 2010; Somero, 2010). Our results suggest that the highly endemic amphibians from the Gran Chaco, as well as some low thermo tolerant temperate species, are in jeopardy because their upper critical temperatures are only slightly above the maximum pond temperatures they currently experience. We must bear in mind that our approach deals with acute thermal stress, yet long-term chronic effects due to diminished physiological, developmental or behavioural performance at elevated temperatures may even result in a greater impact on amphibian populations. Our findings call attention to the importance of estimating whether peaks of high temperature influence larval survival, especially in species having small warming tolerances. It has also been highlighted that estimating micro-habitat climatic variables is essential for a correct risk assessment of global warming. Overgeneralization of the analysis for a biome or climatic zone can lead to erroneous and misleading results such as the divergent warming tolerances between both subtropical communities found in this study. Finally, further research should assess warming tolerances in other tropical and temperate amphibian communities, and should evaluate whether alternative physiological, microevolutionary or behavioural responses may mitigate the impact of climate warming on amphibians.

\section{Acknowledegments}

For their help during the field work and logistic support, special thanks to J.L. Acosta, R. Cajade, M. Duré , A.I. Kehr, J.J. Neiff, N. Oromí, R. Reques and E. Shaefer at the CECOAL-CONICET, UNNE and FCEQyN-UNaM//CONICET (Argentina); D. Álvarez, M. Benítez, J. Bosch, M. Chirosa, D. Donaire, A.G. Nicieza and R. Reques (Spain); A. Laurila, G. Orizaola and B. Rogell (EBC, Uppsala University, Sweden). Special thanks to Z.P. Sousa do Amaral for introducing in the analysis of $\mathrm{CT}_{\max }$ in larval amphibians, and E. Martín-Lorente for designing and building all thermal devices. Raymond B. Huey, Carlos A. Navas, Jason Rohr, David B. Wake and four anonymous reviewers for their comments on earlier versions of the manuscript. All species were sampled and analysed with the permission of the Ministerio de Ecología de la provincia de Misiones (Argentina), Consejería de Medio Ambiente, Junta de Andalucía, Consejería de Medio Ambiente del Principado de Asturias, (Spain), Länsstyrelsen Uppsala Län (Uppsala County, Sweden). This project has been funded by Agencia Españ ola de Cooperación y Desarrollo (AECID) and by the grant CGL2009-12767-C02-02 from the Ministerio de Ciencia e Innovación to MT and CGL2008-04814C02-02 to JFB. ARB was supported by a Spanish Ministry of Education and Culture postdoctoral grant (MEC2007-0944). AGV was funded by a Juan de la Cierva postdoctoral fellowship from the Spanish Ministerio de Ciencia e Innovación.

\section{References}

Addo-Bediako A, Chown SL, Gaston KJ (2000) Thermal tolerance, climatic variability and latitude. Proceedings of the Royal Society B, 267, 739-745.

Battisti DS, Naylor RL (2009) Historical warnings of future food security with unprecedented seasonal heat. Science, 323, 240-244.

Becker CG, Fonseca CR, Haddad CFB, Batista RF, Prado PI (2007) Habitat split and the global decline of amphibians. Science, 318, 1775-1777.

Beebee TJC (1995) Amphibian breeding and climate. Nature, 374, 219-220.

Bernardo J, Spotila JR (2006) Physiological constraints on organismal response to global warming: Mechanistic insights from clinally varying populations and implications for assessing endangerment. Biology Letters, 2, 135-139.

Berven KA (1990) Factors affecting population fluctuations in larval and adult stages of the wood frog (Rana sylvatica). Ecology, 71, 1599-1608.

Bradshaw WE, Holzapfel CM (2006) Evolutionary response to rapid climate change. Science, 312, 1477-1478.

Brattstrom BH (1968) Thermal acclimation in anuran amphibians as a function of latitude and altitude. Comparative Biochemistry and Physiology, 24, 93-111.

Bromham L (2009) Why do species vary in their rate of molecular evolution? Biology Letters, 5, 401-404

Burgos JJ, Fuenzalida-Ponce H (1991) Climate change predictions for South America. Climatic Change, 18, 223-239.

Carey C, Alexander MA (2003) Climate change and amphibian declines: is there a link? Diversity and Distributions, 9, 111-121.

Carroll EJ Jr (1996) Thermal tolerance and heat shock protein synthesis during development in the anuran Lepidobatrachus laevis. Development, Growth \& Differentiation, 38, 9-14.

Cavicchi S, Guerra D, La Torre V, Huey RB (1995) Chromosomal analysis of heatshock tolerance in Drosophila melanogaster evolving at different temperatures in the laboratory. Evolution, 49, 676-684.

Chown SL, Jumbam KR, Sørensen JG, Terblanche JS (2009) Phenotypic variance, plasticity and heritability estimates of critical thermal limits depend on methodological context. Functional Ecology, 23, 133-140.

Clarke A, Gaston KJ (2006) Climate, energy and diversity. Proceedings of the Royal Society B, 273, 2257-2266.

Collins JP, Crump ML (2009) Extinction in Our Times. Global Amphibian Decline. Oxford University Press, Oxford.

Compton TJ, Rijkenberg MJA, Drent J, Piersma T (2007) Thermal tolerance ranges and climate variability: a comparison between bivalves from differing climates. Journal of Experimental Marine Biology and Ecology, 352, 200-211. 
Cowles RB, Bogert CM (1944) A preliminary study of the thermal requirements of desert reptiles. Bulletin of the American Museum of Natural History, 83, 261-296.

Deutsch CA, Tewksbury JJ, Huey RB, Sheldon KS, Ghalambor CK, Haak DC, Martin PR (2008) Impacts of climate warming on terrestrial ectotherms across latitude. Proceedings of the National Academy of Sciences of United States of America, 105, 6668-6672.

Dillon ME, Wang G, Huey RB (2010) Global metabolic impacts of recent climate warming. Nature, 467, 704-707.

Feder ME, Lynch JF (1982) Effects of latitude, season, elevation, and microhabitat on field body temperatures of neotropical and temperate zone salamanders. Ecology, 63, 1657-1664.

Felsenstein J (1985) Phylogenies and the comparative method. The American Naturalist, $125,1-15$.

Floyd RB (1983) Ontogenetic change in the temperature tolerance of larval Bufo marinus (Anura: Bufonidae). Comparative Biochemistry and Physiology, 75A, 267-271.

Freckleton RP, Harvey PH, Pagel M (2002) Phylogenetic analysis and comparative data: a test and review of evidence. The American Naturalist, 160, 712-726.

Frost DR, Grant T, Faivovich J et al. (2006) The amphibian tree of life. Bulletin of the American Museum of Natural History, 297, 1-371.

Garland TJ, Harvey PH, Ives AR (1992) Procedures for the analysis of comparative data using phylogenetically independent contrasts. Systematic Biology, 41, 18-32.

Ghalambor CK, Huey RB, Martin PR, Tewksbury JJ, Wang G (2006) Are mountain passes higher in the tropics? Janzen's hypothesis revisited. Integrative and Comparative Biology, 46, 5-17.

Gosner KL (1960) A simplified table for staging anuran embryos and larvae with notes on identification. Herpetologica, 16, 183-190.

Harmon L, Weir J, Brock C, Glor R, Challenger W, Hunt G (2009) Geiger: Analysis of Evolutionary Diversification. R package version 1.3-1. Available at: http://CRAN. R-project.org/package=geige (accessed 22 August 2011).

Harvey PH, Pagel MD (1991) The Comparative Method in Evolutionary Biology. Oxford University Press, Oxford.

Hayes TB, Falso P, Gallipeau S, Stice M (2010) The cause of global amphibian declines: a developmental endocrinologist's perspective. Journal of Experimental Biology, 213, 921-933.

Helmuth B, Broitman BR, Yamane L, Gilman SE, Mach K, Mislan KAS, Denny MW (2010) Organismal climatology: analyzing environmental variability at scales relevant to physiological stress. Journal of Experimental Biology, 213, 995-1003.

Hochachka PW, Somero GN (2002) Biochemical Adaptation: Mechanism and Process in Physiological Evolution. Oxford University Press, Oxford.

Hoffmann AA (2010) Physiological climatic limits in Drosophila: patterns and implications. Journal of Experimental Biology, 213, 870-880.

Hoffmann M, Hilton-Taylor C, Angulo A et al. (2010) The impact of conservation on the status of the world's vertebrates. Science, 330, 1503-1509.

Hoffmann AA, Anderson A, Hallas R (2002) Opposing clines for high and low temperature resistance in Drosophila melanogaster. Ecology Letters, 5, 614-618.

Hoppe DM (1978) Thermal tolerance in tadpoles of the chorus frog Pseudacris triseriata. Herpetologica, 34, 318-321.

Houle D (1992) Comparing evolvability and variability of quantitative traits. Genetics, 130, 195-204.

Huey RB, Deutsch CA, Tewksbury JJ, Vitt LJ, Hertz PE, Álvarez Pérez HJ, Garland T Jr (2009) Why tropical forest lizards are vulnerable to climate warming. Proceedings of the Royal Society B, 276, 1939-1948.

Hutchison VH (1961) Critical thermal maxima in salamanders. Physiological Zoology, 34, 92-125.

Hutchison VH, Dupré RK (1992) Thermoregulation. In: Environmental Physiology of the Amphibians (eds Feder ME, Burggren WM), pp. 206-249. The University of Chicago Press, Chicago.

IPCC (2007) Climate Change 2007. The Physical Science Basis. Contribution of Working Group 1 to the Fourth Assessment Report of the Intergovernmental Panel on Climate Change. Cambridge University Press, Cambridge, UK and New York, NY, USA.

Ives AR, Midford PE, Garland T Jr (2007) Within-species variation and measurement error in phylogenetic comparative methods. Systematic Biology, 56, 252-270.

Kearney M, Shine R, Porter WP (2009a) The potential for behavioural thermoregulation to buffer 'cold-blooded' animals against climate warming. Proceedings of the National Academy of Sciences of United States of America, 106, 3835-3840.

Kearney M, Porter WP, Williams C, Ritchie S, Hoffmann AA (2009b) Integrating biophysical models and evolutionary theory to predict climatic impacts on species' ranges: the dengue mosquito Aedes aegypti in Australia. Functional Ecology, 23, 528538.

Kellermann V, van Heerwaarden B, Sgrò C, Hoffmann AA (2009) Fundamental evolutionary limits in ecological traits drive Drosophila species distributions. Science, 325, 1244-1246.
Lutterschmidt WI, Hutchison VH (1997) The critical thermal maximum: history and critique. Canadian Journal of Zoology, 75, 1561-1574.

Mahoney JJ, Hutchison VH (1969) Photoperiod acclimation and 24-h variations in the critical thermal maxima of a tropical and a temperate frog. Oecologia, 2, 143-161.

McMenamin SK, Hadly EA, Wright CK (2008) Climatic change and wetland desiccation cause amphibian decline in Yellowstone National Park. Proceedings of the National Academy of Sciences of United States of America, 105, 16988-16993.

Navas CA (1997) Thermal extremes at high elevations in the Andes: physiological ecology of frogs. Journal of Thermal Biology, 22, 467-477.

Navas CA, Gomes FR, Carvalho JE (2008) Thermal relationships and exercise physiology in anuran amphibians: integration and evolutionary implications. Comparative Biochemistry and Physiology A, 151, 344-362.

Newman RA (1989) Developmental plasticity of Scaphiopus couchii tadpoles in an unpredictable environment. Ecology, 70, 1775-1787.

Orme D, Freckleton R, Thomas G, Petzoldt T, Fritz S (2009) CAIC: Comparative Analyses using Independent Contrasts. R package version 1.0.4-94/r94. Available at: http://R-Forge.R-project.org/projects/caic/ (accessed 31 January 2008).

Parmesan C (2006) Ecological and evolutionary responses to recent climate change. Annual Review of Ecology and Systematics, 37, 637-669.

Pörtner HO, Knust R (2007) Climate change affects marine fishes through the oxygen limitation of thermal tolerance. Science, 315, 95-97.

Pörtner HO, Bennett AF, Bozinovic F et al. (2006) Trade-offs in thermal adaptation: the need for a molecular to ecological integration. Physiological and Biochemical Zoology, 79, 95-313.

Pounds LA, Bustamante MR, Coloma LA et al. (2006) Widespread amphibian extinctions from epidemic disease driven by global warming. Nature, 439, 161-167.

R Development core team (2009) R: A Language and Environment for Statistical Computing. R Foundation for statistical computing, Vienna, Austria. ISBN 3-900051-07-0. Available at: http://www.R-project.org (accessed 24 August 2009).

Rezende EL, Tejedo M, Santos M (2011) Estimating the adaptive potential of critical thermal limits: methodological problems and evolutionary implications. Functional Ecology, 25, 111-121.

Root TL, Price JT, Hall KR, Schneider SH, Rosenzweig C, Pounds JL (2003) Fingerprints of global warming on wild animals and plants. Nature, 421, 37-42.

Schwenk K, Padilla DK, Bakken GS, Full RJ (2009) Grand challenges in organismal biology. Integrative and Comparative Biology, 49, 7-14.

Semlitsch RD, Scott DE, Pechmann JHK (1996) Structure and dynamics of an amphibian community: evidence from a 16-year study of a natural pond. In: Long-Term Studies of Vertebrate Communities (eds Cody ML, Smallwood JA), pp. 217-248. Academic Press, San Diego.

Sherman E (1980) Ontogenetic change in thermal tolerance of the toad Bufo woodhousei fowleri. Comparative Biochemistry and Physiology, 65A, 227-230.

Sinervo B, Méndez de la Cruz F, Miles DB et al. (2010) Erosion of lizard diversity by climate change and altered thermal niches. Science, 328, 894-899.

Skelly DK, Joseph LN, Possingham HP, Kealoha Freidenburg L, Farrugia TJ, Kinnison MT, Hendry AP (2007) Evolutionary responses to climate change. Conservation Biology, 21, 1353-1355.

Snyder GK, Weathers WW (1975) Temperature adaptations in amphibians. The American Naturalist, 109, 93-101.

Somero GN (2002) Thermal physiology and vertical zonation of intertidal animals: optima, limits and cost of living. Integrative and Comparative Biology, 42, 780-789.

Somero GN (2005) Linking biogeography to physiology: evolutionary and acclimatory adjustments of thermal limits. Frontiers in Zoology, 2, 1.

Somero GN (2010) The physiology of climate change: how potentials for acclimatization and genetic adaptation will determine 'winners' and 'losers'. Journal of Experimental Biology, 213, 912-920.

Stillman JH (2003) Acclimation capacity underlies susceptibility to climate change. Science, 301, 65.

Stillman JH, Somero GN (2000) A comparative analysis of the upper thermal tolerance limits of eastern Pacific porcelain crabs, genus Petrolisthes: influences of latitude, vertical zonation, acclimation and phylogeny. Physiological and Biochemical Zoology, 73, 200-208.

Sunday JM, Bates AE, Dulvy NK (2011) Global analysis of thermal tolerance and latitude in ectotherms. Proceedings of the Royal Society B, 278, 1823-1830.

Swofford DL (2003) PAUP*. Phylogenetic Analysis Using Parsimony (*and Other Methods). Version 4.0a110 for Macintosh. Sinauer Associates, Sunderland, Massachusetts.

Terblanche JS, Deere JA, Clusella Trullas S, Janion C, Chown SL (2007) Critical thermal limits depend on methodological context. Proceedings of the Royal Society B, 274, 2935-2942.

Tewksbury JJ, Huey RB, Deutsch CA (2008) Putting the heat on tropical animals. Science, 320, 1296-1297. 
Wake DB, Vredenburg VT (2008) Are we in the midst of the sixth mass extinction? A view from the world of amphibians. Proceedings of the National Academy of Sciences of United States of America, 105, 11466-11473.

Wells KD (2007) The Ecology and Behaviour of Amphibians. University of Chicago Press, Chicago.
Wu C-S, Kam Y-C (2005) Thermal tolerance and thermoregulation by taiwanese rhacophorid tadpoles (Buergeria japonica) living in geothermal hot springs and streams. Herpetologica, 61, 35-46.

\section{Supporting Information}

Additional Supporting Information may be found in the online version of this article:

Table S1. Mean \pm SE of upper critical thermal limits $\left(\mathrm{CT}_{\max }\right)$, maximum pond temperature $\left(\mathrm{T}_{\max }\right)$, mean $\pm \mathrm{SE}$ of warming tolerance (WT), and community of origin for the sampled 47 amphibian larvae species. (n) Number of tested larvae.

Table S2. Identification, thermal information and geographical location of sampled ponds. Min, minimum pond temperature; Mean, mean pond temperature; Max, maximum pond temperature.

Table S3. Accession numbers for the two mitochondrial and three nuclear genes used to construct the phylogeny.

Figure S1. Concatenated phylogenetic tree of 47 amphibian species based on two mitochondrial genes ND1 and cyt b, and three nuclear protein coding genes Tyrosinase, Rhodopsin and RAG-1, with Ambystoma tigrinum set as the outgroup. Branch lengths were estimated over a previous phylogenetic hypothesis (Frost et al., 2006). Scale represents substitutions per site.

Please note: Wiley-Blackwell are not responsible for the content or functionality of any supporting materials supplied by the authors. Any queries (other than missing material) should be directed to the corresponding author for the article. 